\title{
The Impact of CCR5 Polymorphism on the Clinical Outcome of Allogeneic Stem Cell Transplantation
}

\section{Gero Hütter}

Institute of Transfusion Medicine and Immunology, Medical Faculty Mannheim, Heidelberg University; German Red Cross Blood Service Baden-Württemberg - Hessen, Germany

\begin{abstract}
The natural function of the C-C chemokine receptor type 5 (CCR5) is poorly understood. However, polymorphisms of this gene have been described to influence the outcome of allogeneic organ and stem cell transplantation. Most intensively studied is a 32 base pair deletion in the CCR5 gene (CCR5-delta32) located on chromosome 3 which leads to a non-functional protein. It is supposed that this deletion causes an alteration in T-cell response to inflammation. For example, the presence of the CCR5-delta32 allele in recipients of allografts constitutes as an independent and protective factor associated with a decreased risk of graft-versus-host disease (GVHD) and graft rejection. However, the mechanism of this beneficial effect of the deletion regarding GVHD is unknown. Here, we describe the biology of the chemokine receptor CCR5 and its polymorphism in the context of transplantation immunology.
\end{abstract}

Keywords: CCR5; Polymorphism; Host adaptation; Stem cell transplantation

\section{Introduction}

The $\mathrm{C}$-C chemokine receptor type 5 (CCR5) belongs to the super family of the seven-transmembrane G-protein coupled receptors (GPCRs) [1]. It interacts with chemokines that mediate the trafficking and function of memory/effector T-lymphocytes, macrophages, and immature dendritic cells towards sites of inflammation [2]. After activation with chemokine ligands, GPCRs are rapidly phosphorylated at serine and threonine residues within the $\mathrm{C}$-tail and the third intracellular loop [3]. When bound by their ligands, these receptors can be internalized, impairing the subsequent ability to bind their ligands. Once internalized, these receptors tend to recycle to the cell surface in time. Most chemokines activate more than one receptor subtype and like other chemokine receptors, CCR5 can also bind several chemokines [4].

CCR5 has gained prominence as a cofactor for HIV-1 entry. Hence, 74 mutations have been described in this gene up to date (http://www. ensembl.org) including the intensively studied 32 base pair deletion (CCR5-delta32) that introduces a premature stop-codon into the CCR5 locus [5,6]. Epidemiologic studies have shown that the mutation occurs most frequently in the Caucasian population with up to $10-20 \%$ heterozygous and $1 \%$ homozygous carriers, while it can not be found in the Asian, Middle East, African, and the American Indian population [7]. It is hypothesized that the imbalanced distribution of this allele was caused by environmental selective pressure, resulting in positive selection for the delta32 deletion [8].

Over the last decade, a large number of reports focusing on the role of chemokines in the context of allograft rejection have been made [9]. Furthermore, the first CCR5 inhibitors have been tested concerning their therapeutic significance in terms of transplantation immunology $[10,11]$. First clinical data will probably be available soon from a trial introducing the CCR5 inhibitor Maraviroc into allogeneic hematopoietic stem cell transplantation (SCT) from the Abramson Cancer Center of the University of Pennsylvania (NIH clinical trial number: NCT00948753).

The CCR5 gene is mapped to the short arm of chromosome 3 amongst a group of genes that encode multiple chemokine receptors [12]. CCR5 up-regulation has been proposed by NF-kB, but recently it was suggested that gene regulation is modified by the cAMP/ CREP pathway $[13,14]$. The effect of the CCR5-delta32 deletion on the expression on other genes has been intensively investigated for CXCR4 [15]. The aberrant gene product from CCR5-delta32 builds an intracellular complex with the CXCR4 receptor preventing the expression on the cell surface. Although the mechanism is well described there is a controversy on the question whether this complex is sufficient to suppress CXCR4. Furthermore, it is unknown whether the deletion influences the expression of other genes or forms complexes with a second or third protein.

Apart from the role in HIV infection, the CCR5-delta32 mutation seems to be a modulator regarding immune responses and transplantation immunology. There has also been proposed an association of the mutation with the occurrence of allograft rejection and protection against graft-versus-host disease (GVHD) [16,17].

For SCT, testing for at least ten alleles of five HLA genes is required before declaring that donor and recipient are HLA-concordant. However, GVHD can occur even though donor and recipient are HLA-matching as the immune system is still able to recognize other differences in antigenicity and recipients need intensive immunosuppressive medication to prevent the development of GVHD $[18,19]$. Although there are still advances in the treatment of GVHD, this inflammatory immunoreaction is responsible for $15 \%$ of treatment related mortality [20]. Therefore, understanding and manipulating the mechanisms of GVHD is of important scientific and clinical impact.

The molecular basis of the protective effect of CCR5-delta32 is poorly understood. It is still unclear, whether the CCR5-delta32 deletion may have an effect on the expression of genes, which communicate immunological responses or whether the protective effect of the CCR5delta32 deletion is solely caused by the lack of functional CCR5. One

*Corresponding author: Gero Hütter, Institute of Transfusion Medicine and Immunology, Medical Faculty Mannheim, Heidelberg University; German Red Cross Blood Service Baden-Württemberg - Hessen, Germany, E-mail: gero. huetter@medma.uni-heidelberg.de

Received September 13, 2011; Accepted December 16, 2011; Published December 20, 2011

Citation: Hütter G (2011) The Impact of CCR5 Polymorphism on the Clinical Outcome of Allogeneic Stem Cell Transplantation. J Transplant Technol Res S1:004. doi:10.4172/2161-0991.S1-004

Copyright: (c) 2011 Hütter G. This is an open-access article distributed under the terms of the Creative Commons Attribution License, which permits unrestricted use, distribution, and reproduction in any medium, provided the original author and source are credited. 
of the most elaborately investigated but also controversially discussed association of the CCR5-delta32 deletion is the putative suppression of the chemokine receptor CXCR4 [15]. With concern to this, there is only data available from an animal model, in which CCR5 has been blocked by specific inhibitors [21,22].

\section{Physiological function of CCR5}

The exact physiological function of CCR5 has been entirely unknown for a long time. Individuals lacking CCR5 display no remarkable illness and no increased susceptibility towards infectious diseases could be observed until Lim et al. figured out a possible role for CCR5 during infection with the West Nile virus (WNV) [23]. They found an increased risk for individuals with the CCR5-delta32mutation developing fatal encephalitis and therefore suggest that the functional receptor acts by recruiting leukocytes into the infected central nervous system. Nevertheless, CCR5 deficiency is not a risk factor for WNV infection per se, but is a risk factor for both, early and late clinical manifestations after WNV-infection [24].

\section{CCR5 as a host factor aside HIV infection}

Murine models with CCR5 deficiency mice have demonstrated a robust $\mathrm{T}$-cell response to several infectious agents [25]. A vigorous $\mathrm{T}$-cell response is required to recover from acute hepatitis $\mathrm{B}$ virus (HBV) infection. Interestingly, Thio et al. [26] found that CCR5delta32 increases the likelihood of recovery form HBV infection and reduces the development of chronic HBV infection by nearly $50 \%$. Furthermore, this protective effect was exclusively mediated by the CCR5-delta32 deletion and not by any of the other neighboring polymorphisms.

A potential role for the CCR5-delta 32 deletion was suggested also for hepatitis $\mathrm{C}$ infection (HCV), especially for the chronic course of this disease [27]. Chemokines and chemokine receptors my play a role in the IFN-gamma or IL-4 secretion induced by the HCV antigens and therefore may contribute to the clearance or maintainance of the $\mathrm{HC}$ virus. However, currently there is no clear evidence that the CCR5-delta32 polymorphism is associated with the clinical outcome of $\mathrm{HCV}$ infection nor is valuable to predict the response to therapy with interferon-alpha and ribavirin [28,29].

\section{CCR5 polymorphism in organ transplantation and graft rejection}

During subclinical and clinical acute rejection after organ transplantation, transcripts from several inflammatory chemokines (CCL3, CCL5, CXCL9, CXCL10, and CXCL11) and chemokine receptors (CCR5, CCR7, and CXCR3) were significantly increased in allografts, indicating a strong polarization toward a T-helper 1 effector phenotype during rejection. These transcripts also distinguished acutely rejecting allografts from allografts with nonrejection causes of renal dysfunction. Biopsies from patients with stable function without histological evidence of rejection had increased chemokine transcript levels that were qualitatively similar but quantitatively reduced compared with rejecting allografts [30].

Recipients of organ allografts homozygous for CCR5-delta32 show longer survival of transplant function than those with other genotypes (Table 1). This has been shown for renal and liver transplants suggesting that patients with CCR5-delta32 might be candidates for a reduced immunosuppressive therapy $[16,31]$. Furthermore, interaction and blockade of the CCR5 receptor may also reduced alloantigen-specific T lymphocyte proliferation and may be effective in preventing acute and chronic rejection of allograft [32].

\section{CCR5 polymorphism in allogeneic SCT: graft versus host disease}

Chemokines play a crucial role in the pathogenesis of GVHD disease after SCT (Table 2). In experimental models, due to the redundancy of receptor ligand interaction, the deficiency or blockade of a single chemokine does not protect the allograft from acute rejection [16]. However, recent studies have demonstrated that the blockade or absence of a single chemokine receptor does prolong allograft survival in a fully MHC mismatched model [33].

In a study with CCR5-knockout and wild type mice, animals were lethally irradiated and underwent full MHC-mismatch bone marrow transplantation. Observing more cases of GVHD in the group of CCR5-knockout mice, Kuziel et al. [34] concluded that the absence of CCR5 results in donor T-cell expansion with a consecutive higher rate of GVHD. In another animal model, authors demonstrated that CCR5 and CXCR3 combined chemokine blockade is effective in prolonging allograft survival and limiting acute rejection concurrently [35].

A study investigating the CCR5 polymorphism from donors of 186 allografted recipients demonstrated contradicting results to those of Kuziel. Here, the authors suggested that the presence of the CCR5-delta32 allele represents a protective factor regarding the risk of developing GvHD after allogeneic SCT [17]. Previously, Murai et

\begin{tabular}{|l|l|l|l|l|}
\hline No. of patients & Organ & $\begin{array}{l}\text { Genotyping Recipients } \\
\text { (R)/Donor (D) }\end{array}$ & Outcome & Reference \\
\hline 158 & Liver & $\begin{array}{l}\text { (R): CCR5-delta32 } \\
\text { (D): nd }\end{array}$ & AR $\downarrow$ & {$[31]$} \\
\hline 1227 & Kidney & $\begin{array}{l}\text { (R): CCR5-delta32 } \\
\text { (D): nd }\end{array}$ & Allograft Survival $\uparrow$ & {$[16]$} \\
\hline 163 & Kidney & $\begin{array}{l}\text { (R): CCR5-59029-A/G } \\
\text { (D): nd }\end{array}$ & AR $\downarrow$ & {$[42]$} \\
\hline 158 & Heart & $\begin{array}{l}\text { (R): CCR5 No-E } \\
\text { (D): nd }\end{array}$ & EAR $\downarrow$ & {$[43]$} \\
\hline 266 & Liver & $\begin{array}{l}\text { (R): } 8 \text { CCR5 SNPs } \\
\text { (D): nd }\end{array}$ & Not significant & {$[44]$} \\
\hline 384 & Liver & $\begin{array}{l}\text { (R): CCR5-delta32 } \\
\text { (D): CCR5-delta32 }\end{array}$ & $\begin{array}{l}\text { NAS 4fold } \uparrow \\
\text { Not significant }\end{array}$ & {$[45]$} \\
\hline 173 & Kidney & $\begin{array}{l}\text { (R): CCR5-delta32 } \\
\text { CCR5-59029-A/G } \\
\text { (D): nd }\end{array}$ & Not significant & {$[46]$} \\
\hline
\end{tabular}

(nd= not done, $\mathrm{AR}=$ acute rejection, $\mathrm{EAR}=$ early acute rejection, NAS= nonanastomotic biliary strictures)

Table 1: Summary of studies focusing on the outcome of organ transplantation in regard to different CCR5 polymorphism. In most cases, CCR5 genotyping was only performed in recipients.

\begin{tabular}{|l|l|l|l|l|}
\hline $\begin{array}{l}\text { No. of } \\
\text { patients }\end{array}$ & Graft & $\begin{array}{l}\text { Genotyping } \\
\text { Recipients (R)/Donor (D) }\end{array}$ & Outcome & Reference \\
\hline 1370 & MURD & $\begin{array}{l}\text { (R): CCR5(H1/H1) } \\
\text { (D): CCR5(H1/H1) }\end{array}$ & $\begin{array}{l}\text { DFS } \uparrow, \text { OS } \uparrow \\
\text { DFS } \downarrow\end{array}$ & {$[37]$} \\
\hline 349 & $\begin{array}{l}\text { MURD \& } \\
\text { MRD }\end{array}$ & $\begin{array}{l}\text { (R): CCR5-delta32 } \\
\text { (D): CCR5-delta32 }\end{array}$ & $\begin{array}{l}\text { GvHD } \downarrow \\
\text { No acute GvHD* }\end{array}$ & {$[17]$} \\
\hline 1273 & MURD & $\begin{array}{l}\text { (R): nd } \\
\text { (D): CCR5-delta32 }\end{array}$ & GvHD d** & {$[47]$} \\
\hline
\end{tabular}

$(M U R D=$ matched unrelated donor, $M R D=$ matched related donor, $\mathrm{nd}=$ not done $\mathrm{DFS}=$ disease free survival, $\mathrm{OS}=$ overall survival, $\mathrm{GVHD}=$ graft-versus-host disease)

*in the case of CCR5-delta32 for both donor and recipient, respectively **not significant

Table 2: Summary of studies focusing on the outcome of allogeneic hematopoietic stem cell transplantation in regard to different CCR5 polymorphism. 
al. [36] described the recruitment of CCR5-expression CD8+ T-cells during acute liver GVHD in patients after allogeneic SCT.

Most recently, a significant association of the common CCR5 haplotype $(\mathrm{H} 1 / \mathrm{H} 1)$ and advantage of disease free survival and overall survival in recipients of allogeneic SCT has been found. The authors suggested CCR5 genotyping as a new diagnostic and therapeutic strategy for therapy optimization [37].

Although it seems obvious that the protective effect of the CCR5delta32 deletion should be associated with a lack of a proposed immunemodulatory effect of CCR5, the exact mechanism is not detected. Furthermore, there is the question whether the lack of CCR5 alone or some secondary effect or co-regulation could be involved. In a survey of 19 healthy volunteer Hütter et al. [39] searched for a CCR5-delta32 associated regulation of critical genes involved in the immune response and the development of GVHD using a gene array technique. They found several gene differential co-regulated and most interestingly a CD30L upregulation in the CCR5-delta32 group. They assume that $\mathrm{CD} 30$ and its ligand $\mathrm{CD} 30 \mathrm{~L}$ may be an important costimulatory molecule and marker for the physiological balance between TH1/TH2 immune response associated with allograft rejection $[38,39]$.

\section{CCR5 polymorphism in allogeneic SCT: infectious complications}

Reactivation of Epstein-Barr-Virus (EBV) is a serious complication affecting the recipients of allogeneic SCT. Bogunia-Kubik et al. [40] analyzed 92 recipients of allogeneic SCT and their donors concerning EBV load, EBV reactivation and CCR5-delta32 deletion. They found that the incidence of EBV reactivation after early transplantation $(<100$ days) was significantly lower in patients carrying the CCR5-delta32 allele. In a multivariate analysis of patient's medical data, only for age and CCR5-delta32 a significant association as an independent risk factor for EBV reactivation could be detected. The CCR5-delta32 deletion was found to have a protective effect on EBV reactivation whereas in CCR5 wild type patients the CCR5 expression was significantly higher in the group with EBV reactivation.

In another trial on the influence of several polymorphism in the MCP1, IL-10 and CCR5 genes and their association with disease or reactivation of human cytomegalovirus (CMV) were investigated. In this survey, 83 patients (with CMV reactivation) and 71 controls (no CMV reactivation) were analyzed. For the tested five CCR5 polymorphisms, authors found only the rs 1800023 mutation significant associated with CMV reactivation vs. disease. The authors suggest that down-regulation of the cell surface expression of CCR5 reduces the migration of various immune effector cells to sites of inflammation an that there might be a link between CMV-mediated manipulation of IL-10, MCP1, and CCR5 activity and its ability to escape the immune system. Furthermore, testing of high-risk patients for the presence of these single-nucleotide polymorphisms in critical genes like IL-10 or CCR5 might be useful for individualizing antiviral prophylaxis [41].

\section{Conclusions}

Our diagnostic and therapeutic tools in individualized medicine have rapidly advanced during the last years. This enables us, to predict, prevent, diagnose and treat subtypes of diseases in a more efficient way. The role of the CCR5 polymorphism in transplantation medicine offers us a way in improving the therapeutic strategies and in defining additional risk factors during the transplantation procedure. Patients may benefit from these findings regarding to their specific disease processes and will (probably) therefore have a reduced risk regarding development of life-threatening adverse events. Finally, this kind of personalized treatment in regenerative medicine and therapeutics offers the possibility to transform the efficiency of managing diseases from palliation up to cure.

\section{Acknowledgement}

Funded by a grant from the Bill \& Melinda Gates Foundation through the Grand Challenges Initiative.

\section{References}

1. Allen SJ, Crown SE, Handel TM (2007) Chemokine: receptor structure interactions, and antagonism. Annu Rev Immunol 25:787-820.

2. Oppermann M (2004) Chemokine receptor CCR5: insights into structure function, and regulation. Cell Signal 16:1201-1210.

3. Marchese A, Paing MM, Temple BR, Trejo J (2008) G protein-coupled receptor sorting to endosomes and lysosomes. Annu Rev Pharmacol Toxicol 48:601629.

4. Rossi D, Zlotnik A (2000) The biology of chemokines and their receptors. Annu Rev Immunol 18:217-242.

5. Bream JH, Young HA, Rice N, Martin MP, Smith MW, et al. (1999) CCR5 promoter alleles and specific DNA binding factors. Science 284:223.

6. Carrington M, Dean M, Martin MP, O'Brien SJ (1999) Genetics of HIV-1 infection: chemokine receptor CCR5 polymorphism and its consequences. Hum Mol Genet 8:1939-1945.

7. Stephens JC, Reich DE, Goldstein DB, Shin HD, Smith MW, et al. (1998) Dating the origin of the CCR5-Delta32 AIDS-resistance allele by the coalescence of haplotypes. Am J Hum Genet 62:1507-1515.

8. Galvani AP, Novembre J (2005) The evolutionary history of the CCR5-Delta32 HIV-resistance mutation. Microbes Infect 7:302-309.

9. Hancock WW (2002) Chemokines and transplant immunobiology. J Am Soc Nephrol 13:821-824.

10. Schroder C, Pierson RN 3rd, Nguyen BN, Kawka DW, Peterson LB, et al (2007) CCR5 blockade modulates inflammation and alloimmunity in primates. J Immunol 179:2289-2299.

11. Li J, Xia J, Zhang K, Xu L (2009) Suppression of acute and chronic cardiac allograft rejection in mice by inhibition of chemokine receptor 5 in combination with cyclosporine A. J Surg Res 157:81-90.

12. Samson M, Libert F, Doranz BJ, Rucker J, Liesnard C, et al. (1996) Resistance to HIV-1 infection in caucasian individuals bearing mutant alleles of the CCR-5 chemokine receptor gene. Nature 382:722-725.

13. Liu R, Zhao X, Gurney TA, Landau NR (1998) Functional analysis of the proximal CCR5 promoter. AIDS Res Hum Retroviruses 14:1509-1519.

14. Kuipers HF, Biesta PJ, Montagne LJ, van Haastert ES, van der Valk P, et al (2008) CC chemokine receptor 5 gene promoter activation by the cyclic AMP response element binding transcription factor. Blood 112:1610-1619.

15. Alkhatib G (2009) The biology of CCR5 and CXCR4. Curr Opin HIV AIDS 4:96103

16. Fischereder M, Luckow B, Hocher B, Wüthrich RP, Rothenpieler U, et al. (2001) CC chemokine receptor 5 and renal-transplant survival. Lancet 357:1758-1761.

17. Bogunia-Kubik K, Duda D, Suchnicki K, Lange A (2006) CCR5 deletion mutation and its association with the risk of developing acute graft-versus-host disease after allogeneic hematopoietic stem cell transplantation. Haematologica 91:1628-1634.

18. Reddy P, Ferrara JL (2003) Immunobiology of acute graft-versus-host disease. Blood Rev 17:187-194

19. Nowak J (2008) Role of HLA in hematopoietic SCT. Bone Marrow Transplant 42:S71-S76

20. Bacigalupo A, Palandri $F$ (2004) Management of acute graft versus host disease (GvHD). Hematol J 5:189-196.

21. Bastani S, Sherman W, Schnickel GT, Hsieh GR, Bhatia R, et al. (2009) Chemokine receptor blockade with a synthetic nonpeptide compound attenuates cardiac allograft vasculopathy. Transplantation 88:995-1001. 
Citation: Hütter G (2011) The Impact of CCR5 Polymorphism on the Clinical Outcome of Allogeneic Stem Cell Transplantation. J Transplant Technol Res S1:004. doi:10.4172/2161-0991.S1-004

Page 4 of 4

22. Jun L, Kailun Z, Aini X, Lei X, Guohua W, et al. (2010) Combined treatment with chemokine receptor 5 blocker and cyclosporine induces prolonged graft survival in a mouse model of cardiac transplantation. J Heart Lung Transplant 29:461-470.

23. Lim JK, Glass WG, McDermott DH, Murphy PM (2006) CCR5: no longer a "good for nothing" gene--chemokine control of West Nile virus infection. Trends Immunol 27:308-312.

24. Lim JK, McDermott DH, Lisco A, Foster GA, Krysztof D, et al. (2010) CCR5 deficiency is a risk factor for early clinical manifestations of West Nile virus infection but not for viral transmission. J Infect Dis 201:178-185.

25. Algood HM, Flynn JL (2004) CCR5-deficient mice control Mycobacterium tuberculosis infection despite increased pulmonary lymphocytic infiltration. J Immunol 173:3287-3296.

26. Thio CL, Astemborski J, Bashirova A, Mosbruger T, Greer S, et al. (2007) Genetic protection against hepatitis B virus conferred by CCR5Delta32: Evidence that CCR5 contributes to viral persistence. J Virol 81:441-445.

27. Larrubia JR, Benito-Martinez S, Calvino M, Sanz-de-Villalobos E, Parra-Cid $T$ (2008) Role of chemokines and their receptors in viral persistence and liver damage during chronic hepatitis C virus infection. World J Gastroenterol 14:7149-7159.

28. Glas J, Torok HP, Simperl C, König A, Martin K, et al. (2003) The Delta 32 mutation of the chemokine-receptor 5 gene neither is correlated with chronic hepatitis $\mathrm{C}$ nor does it predict response to therapy with interferon-alpha and ribavirin. Clin Immunol 108:46-50

29. Ruiz-Ferrer M, Barroso N, Antinolo G, Aguilar-Reina J (2004) Analysis of CCR5 Delta 32 and CCR2-V64I polymorphisms in a cohort of Spanish HCV patients using real-time polymerase chain reaction and fluorescence resonance energy transfer technologies. J Viral Hepat 11:319-323.

30. Lo D, Weaver T, Kleiner D, Mannon RB, Jacobson LM, et al. (2011) Chemokines and their receptors in human renal allotransplantation. Transplantation 91:7077.

31. Heidenhain C, Puhl G, Moench C, Lautem A, Neuhaus P (2009) Chemokine receptor 5Delta32 mutation reduces the risk of acute rejection in liver transplantation. Ann Transplant 14:36-44.

32. Schnickel GT, Bastani S, Hsieh GR, Shefizadeh A, Bhatia R, et al. (2008) Combined CXCR3/CCR5 blockade attenuates acute and chronic rejection. J Immunol 180:4714-4721.

33. Gao W, Faia KL, Csizmadia V, Smiley ST, Soler D, et al. (2001) Beneficia effects of targeting CCR5 in allograft recipients. Transplantation 72:1199-1205.

34. Welniak LA, Wang Z, Sun K, Kuziel W, Anver MR, et al. (2004) An absence of CCR5 on donor cells results in acceleration of acute graft-vs-host disease. Exp Hematol 32:318-324
35. Schnickel GT, Hsieh GR, Garcia C, Shefizadeh A, Fishbein MC, et al. (2006) Role of CXCR3 and CCR5 in allograft rejection. Transplant Proc 38:3221-3224.

36. Murai M, Yoneyama H, Harada A, Yi Z, Vestergaard C, et al. (1999) Active participation of CCR5(+)CD8(+) T lymphocytes in the pathogenesis of liver injury in graft-versus-host disease. J Clin Invest 104:49-57.

37. McDermott DH, Conway SE, Wang T, Ricklefs SM, Agovi MA, et al. (2010) Donor and recipient chemokine receptor CCR5 genotype is associated with survival after bone marrow transplantation. Blood 115:2311-2318.

38. Pellegrini P, Berghella AM, Contasta I, Adorno D (2003) CD30 antigen: not physiological marker for $\mathrm{TH} 2$ cells but an important costimulator molecule in the regulation of the balance between $\mathrm{TH} 1 / \mathrm{TH} 2$ response. Transpl Immunol 12:49-61.

39. Hütter G, Neumann M, Nowak D, Klein S, Klüter H, et al. (2011) The effect of the CCR5-delta32 deletion on global gene expression considering immune response and inflammation. J Inflamm 8:29.

40. Bogunia-Kubik K, Jaskula E, Lange A (2007) The presence of functional CCR5 and EBV reactivation after allogeneic haematopoietic stem cell transplantation. Bone Marrow Transplant 40:145-150.

41. Loeffler J, Steffens M, Arlt EM, Toliat MR, Mezger M, et al. (2006) Polymorphisms in the genes encoding chemokine receptor 5 , interleukin-10, and monocyte chemoattractant protein 1 contribute to cytomegalovirus reactivation and disease after allogeneic stem cell transplantation. J Clin Microbiol 44:18471850 .

42. Abdi R, Tran TB, Sahagun-Ruiz A, Murphy PM, Brenner BM, et al. (2002) Chemokine receptor polymorphism and risk of acute rejection in human renal transplantation. J Am Soc Nephrol 13:754-758.

43. Simeoni E, Vassalli G, Seydoux C, Ramsay D, Noll G, et al. (2005) CCR5 RANTES and CX3CR1 polymorphisms: possible genetic links with acute heart rejection. Transplantation 80:1309-1315.

44. Li H, Xie HY, Zhou L, Zhen SS (2011) Lack of Association of the Polymorphism of the CCR5 Gene in Liver Recipients With Acute Rejection From China. Exp Clin Transplant 9:252-257.

45. op den Dries S, Buis Cl, Adelmeijer J, Van der Jagt EJ, Haagsma EB, et al. (2011) The combination of primary sclerosing cholangitis and CCR5-Delta32 in recipients is strongly associated with the development of nonanastomotic biliary strictures after liver transplantation. Liver Int 31:1102-1109.

46. Gorgi Y, Sfar I, Jendoubi-Ayed S, Makhlouf M, Rhomdhane TB, et al. (2011) Allograft renal rejection and chemokine polymorphism. Saudi J Kidney Dis Transpl 22:18-23.

47. Ma Q, Gooley TA, Storb RF (2010) CCR5 expression on cells from HLA matched unrelated marrow donors and graft-versus-host disease. Biol Blood Marrow Transplant 16:132-133.
This article was originally published in a special issue, Post-Transplantation Disorders handled by Editor(s). Dr. Piergiorgio Messa, IRCCS Fondazione Ca Granda, Italy; Dr. Cheguevara I Afaneh, Weill Cornell Medical College, USA; Dr. Shaoyan Hu, The Children's Hospital of Soochow University, China 